\title{
PPP1R15A wt Allele
}

National Cancer Institute

\section{Source}

National Cancer Institute. PPP1R15A wt Allele. NCI Thesaurus. Code C97252.

Human PPP1R15A wild-type allele is located in the vicinity of 19q13.2 and is approximately $4 \mathrm{~kb}$ in length. This allele, which encodes protein phosphatase 1 regulatory subunit $15 \mathrm{~A}$ protein, plays a role in both the modulation of phosphatase activity and signal transduction. 